\title{
Influence of substitution of Portland cement CP-II-Z32 by refractory cement on residual properties of high-temperature concrete
}

\section{(Influência da substituição do cimento Portland CP-II-Z32 por cimento refratário nas propriedades residuais do concreto de alta temperatura)}

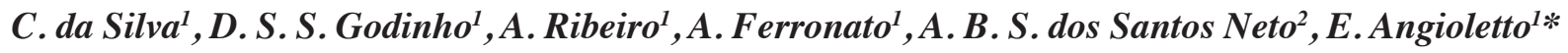 \\ ${ }^{1}$ Universidade do Extremo Sul Catarinense, Programa de Pós-Graduação em Ciências e \\ Engenharia de Materiais, Av. Universitária 1106, 88806-000, Criciúma, SC, Brazil \\ ${ }^{2}$ Universidade Federal de Santa Maria, Programa de Pós-Graduação em Engenharia Civil, \\ Santa Maria, RS, Brazil
}

\begin{abstract}
Concrete structures must be sized to ensure stability over their lifetime. Moreover, there are criteria that must be followed for fire safety verification. Given this context, this study aimed to evaluate the influence of the partial and integral replacement of CPII-Z32 cement by a refractory cement in concrete compositions related to the residual properties after exposure to different temperature levels. For the tests, cylindrical specimens were molded with cement replacement percentages of $0 \%$ (reference), $50 \%$, and $100 \%$, and exposed at $450{ }^{\circ} \mathrm{C}$ and $900{ }^{\circ} \mathrm{C}$ without load. The results showed a change in the color of the specimens and a reduction of the mechanical strength with increasing temperature. The increase in the percentage of refractory cement resulted in lower heat conduction for the concrete made with this material.
\end{abstract}

Keywords: concrete, refractory cement, high temperatures.

Resumo

As estruturas de concreto devem ser dimensionadas para garantir estabilidade ao longo da vida útil. Além disso, existem critérios que devem ser seguidos para a verificação da segurança contra incêndio. Nesse contexto, este trabalho teve como objetivo avaliar a influência da substituição parcial e integral do cimento CPII-Z32 pelo cimento refratário em composições de concreto relacionadas às propriedades residuais após exposição a diferentes níveis de temperatura. Para os testes, amostras cilíndricas foram moldadas com percentuais de substituição de cimento de $0 \%$ (referência), $50 \%$ e $100 \%$ e expostas em 450 e $900{ }^{\circ} \mathrm{C}$ sem carga. Os resultados dos testes mostraram alteração na cor dos corpos de prova e ainda redução da resistência mecânica com o aumento da temperatura. $O$ incremento no percentual de cimento refratário resultou em menor condução de calor para o concreto fabricado com este material. Palavras-chave: concreto, cimento refratário, altas temperaturas.

\section{INTRODUCTION}

There is growing concern regarding the effect of high temperature on concrete owing to the fact that at elevated temperatures, chemical and physical transformations in the aggregates and pastes are developed, and small pores and microcracks are formed within the concrete element [1]. High temperature is known to seriously damage the concrete microstructure and mesostructure, which causes overall mechanical deterioration of the concrete, and even detrimental structural effects due to concrete fragmentation and flame exposure in the event of fire [2]. In recent years, there has been a concern for the development of refractory materials [3]. Due to this need, research in this area is being

*ean@unesc.net

Dhttps://orcid.org/0000-0003-4417-3440 developed. For alumina refractory castables, it was found that the firing temperature influences the thermomechanical behavior [4-6], in addition to research using stainless steel fiber reinforced refractory concrete to improve thermal behavior [7].

At the macroscopic level, ordinary Portland cement concrete is a composite material consisting of discrete aggregates dispersed in a continuous matrix of cement paste. As with other composites, the bonding region or transition zone in the matrix-aggregate concrete is a critical component of the mechanical performance. The microstructure in the transition zone is characterized by high porosity, composed of relatively large pores [2]. The changes that occur in the mechanical properties of concrete when exposed to high temperatures are directly linked to the changes in the microstructural properties of the material [8]. The strength of a concrete sample changes based on its sample size [9], that is, samples of smaller mass and volume, when 
exposed to high temperatures, can exhibit microcracking and chipping due to the thermal incompatibility of the different components, type of aggregate, heating rate, initial humidity, and permeability [1]. In addition to these factors, the properties of refractory concrete depend mainly on the type of binder and fine refractory additives used for its manufacture [3].

The probability of a structural collapse in a reinforced concrete building in a fire situation, although small, is not uncommon, and it can result in the loss of property and human lives. Over time, these occurrences and concerns have promoted a concept of fire safety and mechanisms associated with its prevention or limitation of the damage caused. Thus, the conception of a structural project should consider safety factors that aim at the preservation of life and heritage. Engineering should be based on the safety and durability of the building. In this context, due to the scarcity of research in this area, the present work aims to study the influence on the residual and microstructural properties of concrete made with partial and total replacement of the Portland CPII-Z32 cement by a refractory cement, verified at room temperature (reference) and after exposure at 450 and $900{ }^{\circ} \mathrm{C}$.

\section{MATERIALS AND METHODS}

Materials. Concrete: Portland CPII-Z32 cement, coarse granite aggregate (gravel 1, $19 \mathrm{~mm}$ ), and washed medium sand were used. The refractory cement was type EL-70 GUN (Elfusa). The chemical composition of the Portland CPII-Z32 and EL-70 GUN refractory cements are presented in Table I. The studied concrete composition was obtained by the IPT/EPUSP dosing method with a consistency of $60 \pm 10 \mathrm{~mm}$. The unit composition of concrete used by mass was 1:2.64:3.36:0.588 (cement:sand:gravel:water) for a characteristic compressive strength of $25 \mathrm{MPa}$.

Methods. Specimens: a total of 135 cylindrical specimens were molded (10 $\mathrm{cm}$ in diameter and $20 \mathrm{~cm}$ in height). The specimens were molded into 3 different compositions:

Table I - Chemical composition of the cements used (\%). [Tabela I - Composição química dos cimentos utilizados (\%).]

\begin{tabular}{ccc}
\hline Oxide & CPII-Z32 & EL-70 GUN \\
\hline $\mathrm{Al}_{2} \mathrm{O}_{3}$ & 4.00 & 67.42 \\
$\mathrm{SiO}_{2}$ & 15.10 & 3.04 \\
$\mathrm{FeO}$ & 4.07 & 0.42 \\
$\mathrm{MgO}$ & 5.26 & 0.34 \\
$\mathrm{CaO}$ & 63.62 & 28.10 \\
$\mathrm{Na}_{2} \mathrm{O}$ & $<0.05$ & 0.13 \\
$\mathrm{SO}_{3}$ & 4.41 & $<0.05$ \\
$\mathrm{P}_{2} \mathrm{O}_{3}$ & 1.66 & $<0.05$ \\
$\mathrm{TiO}_{2}$ & 0.49 & $<0.05$ \\
\hline
\end{tabular}

composition 1, 100\% Portland CPII-Z32 cement; composition $2,100 \%$ refractory cement; and composition 3, a mixture of Portland CPII-Z32 (50 wt $\%$ ) and refractory cement (50 wt \%). Curing of specimens: after demolding and before beginning the testing, the specimens were submerged in a water tank for 28 days [10] and subsequently stored at room temperature for a total period of 90 days. Heating of specimens: after 90 days, the specimens were heated at 450 and $900{ }^{\circ} \mathrm{C}$, with a heating rate of $3^{\circ} \mathrm{C} / \mathrm{min}$ [11], and holding time at the maximum temperature of $30 \mathrm{~min}$; then, the oven was turned off, and the specimens remained inside it until the oven naturally cooled.

Characterizations: for each test temperature $(25,450$, and $900{ }^{\circ} \mathrm{C}$ ), the color changes that occurred for each composition were visually checked. For X-ray diffraction (XRD) analysis, the samples were fragmented, milled, and sieved (sieve $200 \mu \mathrm{m}$ ) to obtain a thin and uniform material. The XRD analysis was performed on a diffractometer (Shimadzu, LabX XRD 6000) with scanning from $3^{\circ}$ to $80^{\circ}$ of $2 \theta$ and speed of $2 \%$ min (using $25 \mathrm{kV}$ and 25 $\mathrm{mA}$ ). The thermal analysis (thermogravimetry/differential scanning colorimetry, TG/DSC) of the concrete sample was performed in a synthetic air atmosphere in the temperature range from 20 to $1000{ }^{\circ} \mathrm{C}$ with a heating rate of $10^{\circ} \mathrm{C} / \mathrm{min}$, in a simultaneous TG/DSC equipment (TA Instr., Q600). A study of the thermal behavior of the samples was also performed, and two specimens were submitted to heating and cooling and monitored by thermocouples installed on the outside and in the center of the samples. The heating rate used was $5{ }^{\circ} \mathrm{C} / \mathrm{min}$. For data collection over time, a data logger was used. The purpose of this thermal study was to analyze how the heating of each composition occurred. The tests of the axial compression strength, tensile strength by diametral compression, and Young's modulus were performed in a hydraulic press with a maximum capacity of $2000 \mathrm{kN}$ (Emic) following the recommendations of RILEM TC 129 MHT, NBR 7222, and NBR 8522 standards [1214]. Five specimens were used for each composition and for each temperature level. The mass loss of the specimens was obtained by the difference between the masses before and 24 $\mathrm{h}$ after heating, which were measured at $25^{\circ} \mathrm{C}$. The balance used for the weighing of the specimens had a capacity of $5000 \mathrm{~g}$ (Mars, AS 5000). For scanning electron microscopy (SEM), a microscope (Zeiss, MA10) was used; the samples were sectioned with a precision cutter (Buehler, Isomet 1000), sanded, polished, and dried in an oven at $105^{\circ} \mathrm{C}$ before analysis.

\section{RESULTS AND DISCUSSION}

Color change: it was possible to observe the color change of the specimens after heating at 450 and $900{ }^{\circ} \mathrm{C}$ for the three compositions (Fig. 1). In the process of increasing the temperature, concrete changed its color. It was noticed that at $450{ }^{\circ} \mathrm{C}$, the color of the specimens was pinkish, and at $950{ }^{\circ} \mathrm{C}$, the color changed to gray with reddish points; moreover, the compressive strength was significantly 


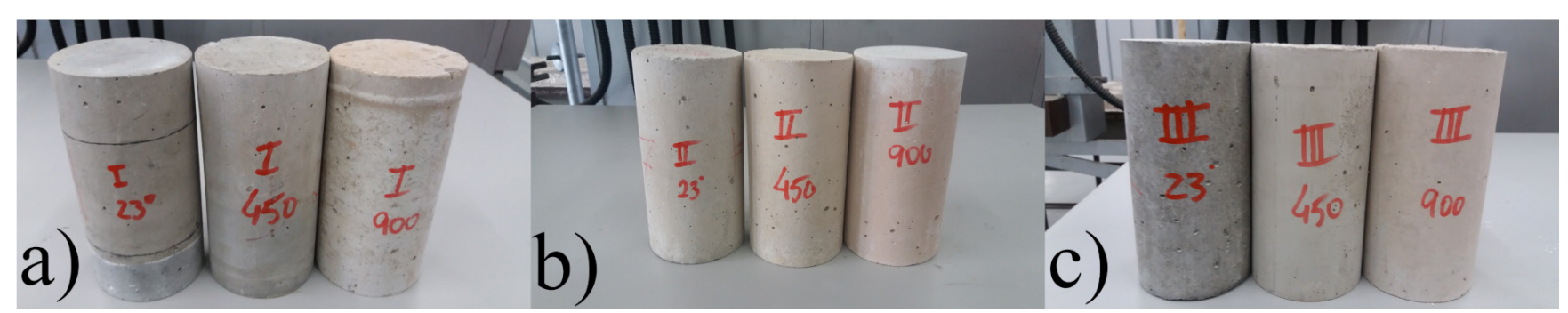

Figure 1: Images showing the color of the samples with composition 1 (a), 2 (b), and 3 (c), before $\left(23^{\circ} \mathrm{C}\right)$, and after heating at 450 and $900{ }^{\circ} \mathrm{C}$. [Figura 1: Imagens mostrando a cor das amostras com composição 1 (a), 2 (b) e 3 (c), antes $\left(23^{\circ} \mathrm{C}\right)$ e após aquecimento a 450 e $900{ }^{\circ} \mathrm{C}$.]

reduced. This result corroborated that reported by Yuzer et al. [15], who indicated that the concrete gradually changes the presented shade when exposed to temperature. Changes in color can be attributed to chemical changes, mainly by dehydroxylation of the hydrated phases [6].

$X$-ray diffraction: the diffractograms indicated that the three compositions showed the presence of quartz $\left(\mathrm{SiO}_{2}\right)$, portlandite $\left[\mathrm{Ca}(\mathrm{OH})_{2}\right]$, and calcite $\left(\mathrm{CaCO}_{3}, \mathrm{Fig}\right.$.2). Portlandite appeared stable for the samples at room temperature and less intense at $450{ }^{\circ} \mathrm{C}$, as the decomposition by dehydration of this compound begins near $530{ }^{\circ} \mathrm{C}$. Calcium oxide $(\mathrm{CaO})$ was not detected in the analyses, which typically appears at temperatures near $600{ }^{\circ} \mathrm{C}$, as this compound is formed by the decomposition of portlandite and calcite. Calcite was present at all temperatures, however, with more significant peaks for samples at room temperature, as found in another study [16]. Another factor that must be considered is the sampling for analysis since aliquots were taken from both the internal and external regions of the cylindrical specimens, which were exposed to different temperature profiles during the heating.

Calorimetry and thermogravimetric analysis: Fig. 3 shows the results of the thermal analyzes. With increasing temperature, mass loss was observed for the three compositions. Sudden changes in the slope indicate the temperatures where the most severe mass loss occurs, which can be associated with phase changes or chemical transformations. Thermogravimetric analysis (TG) indicated that there was a similar behavior among the curves for the three compositions. The mass decrease between the initial temperature and $100{ }^{\circ} \mathrm{C}$ was associated with the initial loss of absorbed water contained in the capillaries. This appeared as an endothermic peak in the DSC curve [16]. Hydration products completely lose free water and physically absorbed water and begin to lose their chemically bound water at $105{ }^{\circ} \mathrm{C}$ [17]. For composition 1, a gradual loss of mass occurred from 100 to $550{ }^{\circ} \mathrm{C}$. Between 100 and $420^{\circ} \mathrm{C}$, the decomposition of hydrated calcium silicate (C-S-H) began, which was accompanied by a gradual loss of mass [16]. Capillary water was completely lost at $400{ }^{\circ} \mathrm{C}$, corroborating other research [18], and between 550 and $700{ }^{\circ} \mathrm{C}$, there was a steep slope in the TG curve and an endothermic peak in the DSC curve, which can be attributed to the dehydroxylation of portlandite. Near $800{ }^{\circ} \mathrm{C}$, an endothermic peak occurred that can be explained by the loss of carbon dioxide from the calcium carbonate that was formed by the dehydration of the calcium hydroxide [16]. For compositions 2 and 3, between room temperature and $200{ }^{\circ} \mathrm{C}$, an endothermic peak can be attributed to the dehydration of $\mathrm{CAH}_{10}\left(\mathrm{CaO} \cdot \mathrm{Al}_{2} \mathrm{O}_{3} \cdot 10 \mathrm{H}_{2} \mathrm{O}\right)$. Between 200 and $300{ }^{\circ} \mathrm{C}$, dehydration of $\mathrm{AH}_{3}\left(\mathrm{Al}_{2} \mathrm{O}_{3} \cdot 3 \mathrm{H}_{2} \mathrm{O}\right)$ occurred, followed by dehydration of the $\mathrm{C}_{3} \mathrm{AH}_{6}$ (3CaO. $\mathrm{Al}_{2} \mathrm{O}_{3} \cdot 6 \mathrm{H}_{2} \mathrm{O}$ ). The mass reduction at $700{ }^{\circ} \mathrm{C}$ indicated that
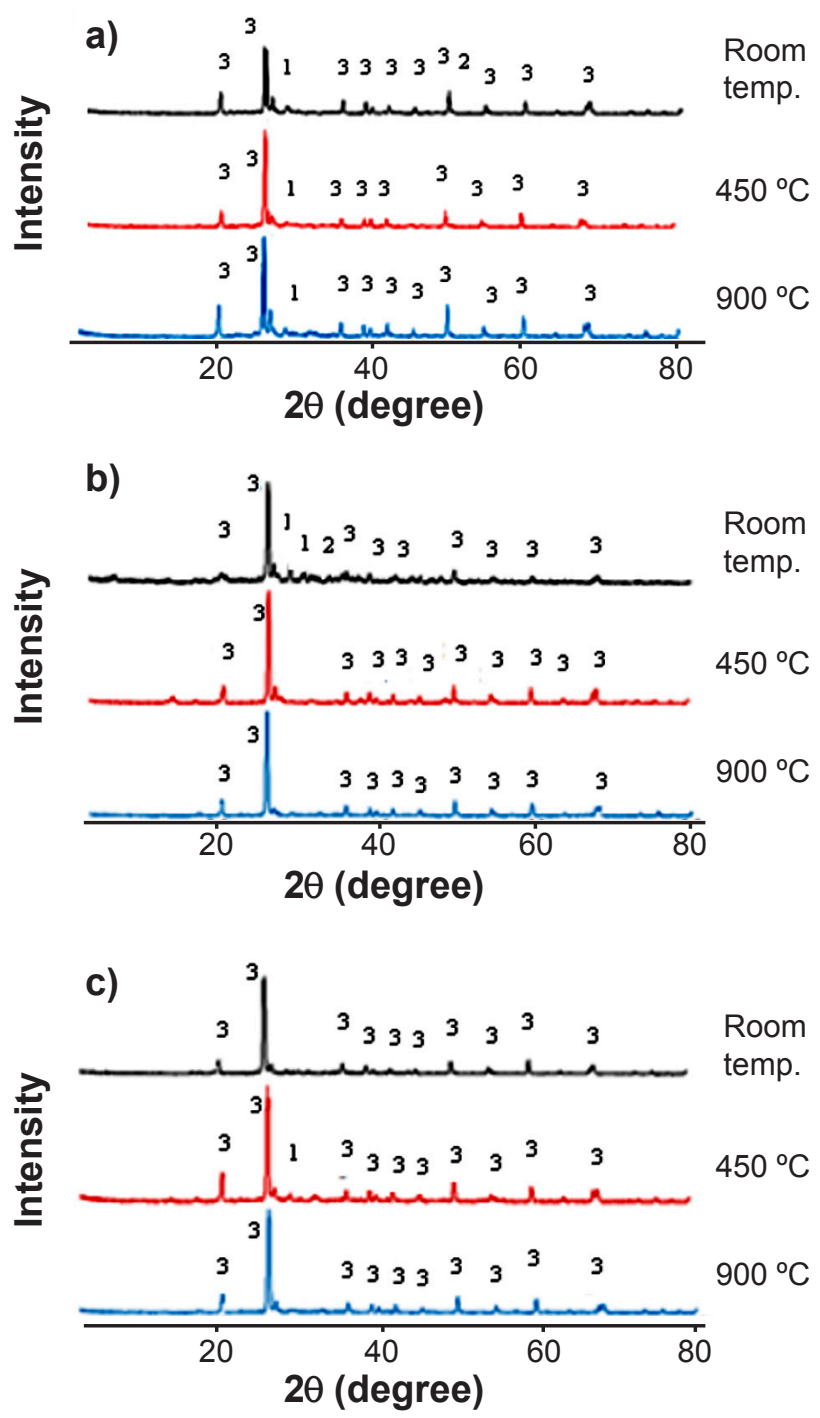

Figure 2: XRD patterns of the samples with composition 1 (a), 2 (b) and 3 (c). 1: calcite $\left(\mathrm{CaCO}_{3}\right.$, JCPDS 5-0586); 2: portlandite $\left[\mathrm{Ca}(\mathrm{OH})_{2}\right.$, JCPDS 4-0733]; 3: quartz ( $\mathrm{SiO}_{2}$, JCPDS 46-1045).

[Figura 2: Padrões de DRX das amostras com composição 1 (a), 2 (b) e 3 (c). 1: calcita; 2: portlandita; 3: quartzo.] 
the majority of the calcium aluminate cement hydrates was decomposed. The exothermic peak for composition 2 between $750{ }^{\circ} \mathrm{C}$ to approximately $900{ }^{\circ} \mathrm{C}$ could be due to the crystallization of $\mathrm{CA}\left(\mathrm{CaO} \cdot \mathrm{Al}_{2} \mathrm{O}_{3}\right)[19,20]$.
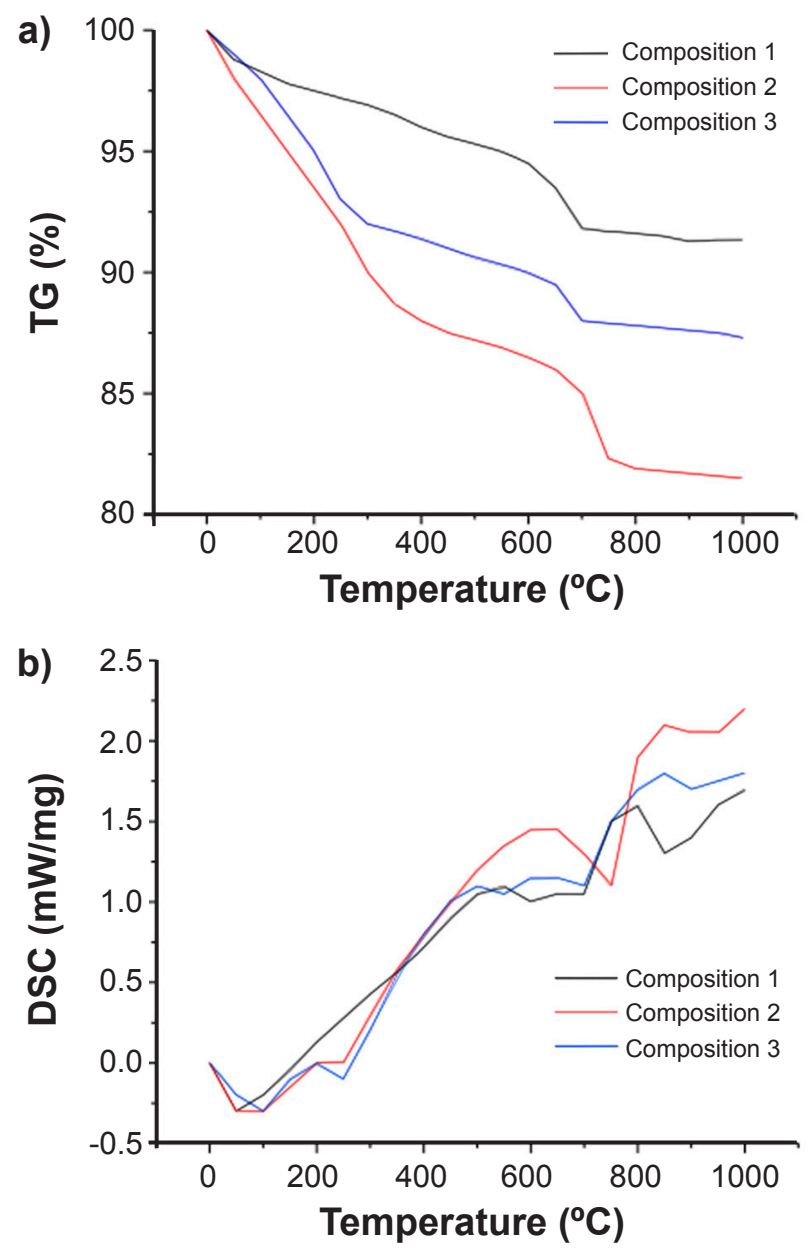

Figure 3: TG (a) and DSC (b) curves of the concrete samples with composition 1,2 , and $3(0,100 \%$, and $50 \%$ of refractory cement, respectively).

[Figura 3: Curvas de TG (a) e DSC (b) das amostras de concreto com composição 1, 2 e $3(0,100 \%$ e 50\% de cimento refratário, respectivamente).]

Thermal behavior: Fig. 4 shows the thermal behavior of the compositions. The extremes of the compositions were studied: composition 1 with $0 \%$ refractory cement; and composition 2 with $100 \%$ refractory cement. Probably, the thermal behavior of composition 3 (50\% refractory cement) would be in this range. The thermocouple positioned on the outside of the composition 1 specimen recorded a maximum temperature of $868{ }^{\circ} \mathrm{C}$ at $200 \mathrm{~min}$; at that same time, the internal thermocouple recorded $806{ }^{\circ} \mathrm{C}$ (Fig. 4a). The thermocouple inside the specimen required $218 \mathrm{~min}$ to attain a maximum temperature of $842{ }^{\circ} \mathrm{C}$, while the external temperature was $756{ }^{\circ} \mathrm{C}$. A difference of $26^{\circ} \mathrm{C}$ was found between the maximum temperatures recorded between the outer face and the center of the specimen, and 18 min was the time difference between them. Analyzing the results obtained for the composition 2 specimen, it appeared that the external thermocouple required $223 \mathrm{~min}$ to record the maximum temperature of $862{ }^{\circ} \mathrm{C}$ on the surface of the specimen; at that same time, the internal temperature was $812{ }^{\circ} \mathrm{C}$. The internal thermocouple indicated a maximum temperature of $826{ }^{\circ} \mathrm{C}$ at $232 \mathrm{~min}$; simultaneously, the external temperature was $712^{\circ} \mathrm{C}$. The difference between the maximum external and internal temperatures of the specimen was $36^{\circ} \mathrm{C}$, with 9 min difference between them.
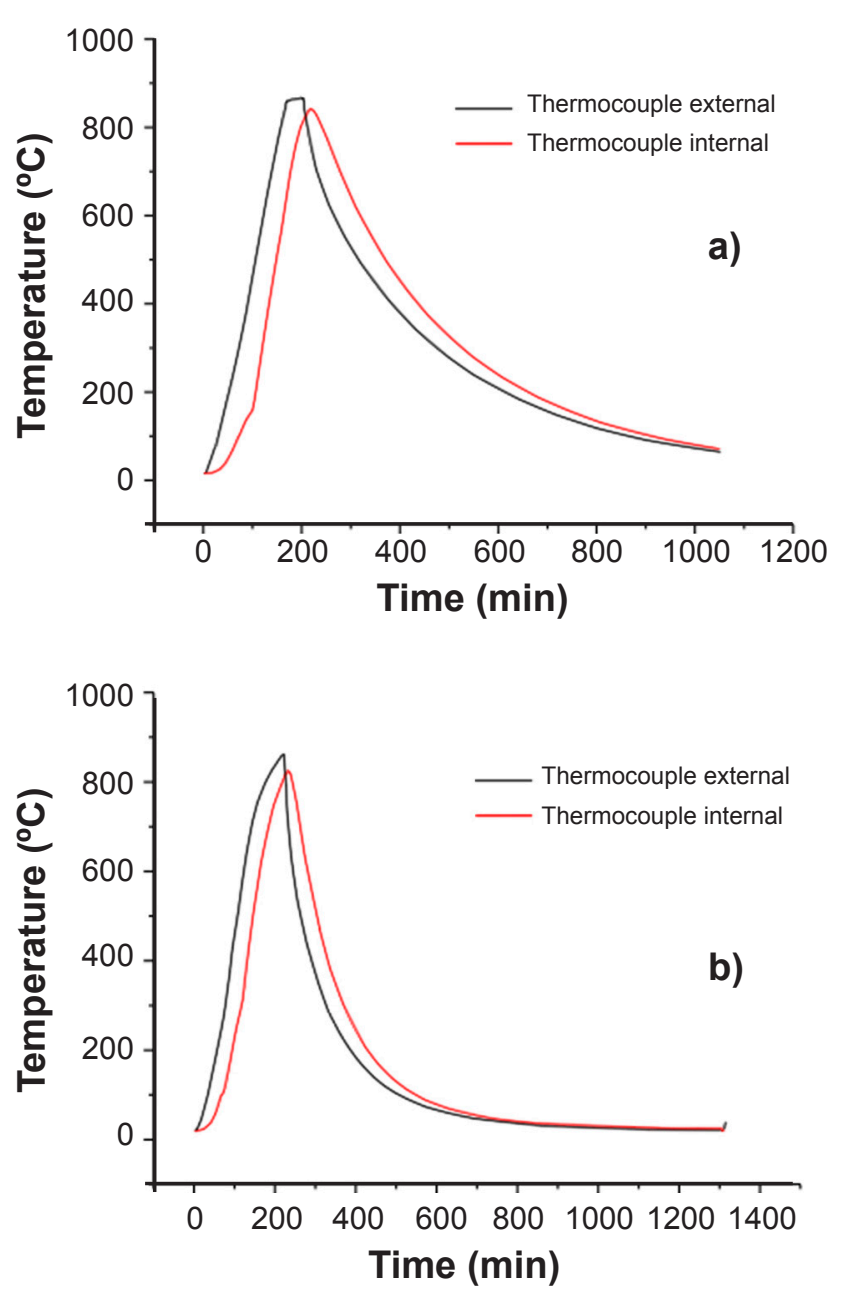

Figure 4: Temperature as a function of time of the outer face and center of the cylindrical specimen $(\phi 10 \times 20 \mathrm{~cm})$ during the heating at $900{ }^{\circ} \mathrm{C}$ for the composition 1 (a) and 2 (b).

[Figura 4: Temperatura em função do tempo da face externa e do centro de corpo cilíndrico $(\phi 10 \times 20 \mathrm{~cm})$ durante o aquecimento a $900{ }^{\circ} \mathrm{C}$ para a composição 1 ( a ) e $\left.2(b).\right]$

The maximum difference between the external and internal temperatures (Fig. 5) of the composition 1 specimen was $309^{\circ} \mathrm{C}$ at $105 \mathrm{~min}$. At this time, the external temperature recorded was $495^{\circ} \mathrm{C}$, whereas the internal temperature was $186{ }^{\circ} \mathrm{C}$. The maximum difference obtained between the external and internal temperatures of the composition 2 specimen occurred at $123 \mathrm{~min}$ with a variation of $279^{\circ} \mathrm{C}$. At this time, the external temperature recorded was $603^{\circ} \mathrm{C}$, and 
the internal temperature was $324{ }^{\circ} \mathrm{C}$. That is, the maximum difference between the external and internal temperatures was $30^{\circ} \mathrm{C}$ higher for the composition 1 specimen. This specimen required a shorter time to reach the maximum surface temperature and had the maximum internal temperature $16{ }^{\circ} \mathrm{C}$ higher than that of composition 2. Similarly, the maximum temperature inside the composition 1 specimen was recorded 14 min earlier than the maximum temperature recorded inside the composition 2 specimen, demonstrating reduced heat conduction inside the concrete made with the refractory cement. This fact could be correlated to the dehydration of the calcium aluminate cement, in particular the dehydration of $\mathrm{C}_{3} \mathrm{AH}_{6}$ and $\mathrm{AH}_{3}$ [21].

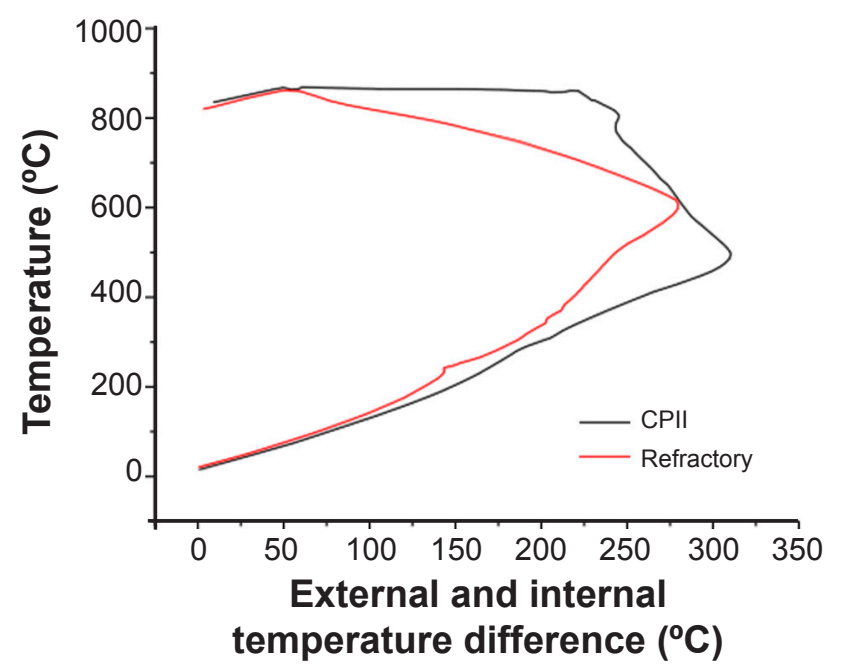

Figure 5: Graph of external and internal temperature difference for composition 1 (CPII) and 2 (Refractory).

[Figura 5: Gráfico de diferença de temperatura externa e interna para a composição 1 (CPII) e 2 (Refractory).]

Axial compressive strength: Fig. 6a shows the axial compression strength of the compositions as a function of temperature. For compositions 1 and 3 , the axial compressive strength decreased with increasing temperature. For composition 2 , there was an increase in strength at $450{ }^{\circ} \mathrm{C}$, followed by reduction at $900^{\circ} \mathrm{C}$. Between 300 and $800^{\circ} \mathrm{C}$, the compressive strength of the concrete decreased dramatically since above $350{ }^{\circ} \mathrm{C}$, the calcium hydroxide decomposes into lime and water or becomes C-S-H owing to the accelerated high-temperature pozzolanic reaction [22-24]. Concerning chemical and mineralogical compositions, the refractory cement (EL-70 GUN) and CP-II-Z32 had marked differences in their chemical compositions (Table I), which induced the formation of different hydration products. The significant difference in the amount of alumina and also in the contents of calcium and silicon oxides were the main cause for the different mechanical behaviors, since alumina is a refractory material with excellent resistance to high temperatures with lower coefficients of thermal expansion, while the smaller amount of quartz minimized the occurrence of free quartz. The presence of quartz can be one of the causes of cracks due to the phase transformation. In previous studies, different authors found significant differences when measuring the mechanical properties of the two cements when tested in similar situations. These differences tend to stand out with the increase in temperature because there are decomposition reactions of these products in different ways, which induce a different behavior regarding the tensile strength $[25,26]$.

Above $400{ }^{\circ} \mathrm{C}$, portlandite dehydration also occurs, which causes shrinkage and microfissure of the cement paste, and increases the porosity of the concrete, thus contributing to the reduction of the axial compressive strength of the concrete [8]. C-S-H begins to decompose near $560{ }^{\circ} \mathrm{C}$ and decomposes into $\beta-\mathrm{C}_{2} \mathrm{~S}$ in the range of 600 to $700{ }^{\circ} \mathrm{C}[23$, 27]. At $800^{\circ} \mathrm{C}$, changes occur in the chemical bonds, with the replacement of the hydraulic structure by a ceramic structure [16] and above $800^{\circ} \mathrm{C}$ virtually all the compressive strength of the concrete is lost [2]. The increase in the compressive strength of the concrete observed for composition 2 at $450{ }^{\circ} \mathrm{C}$ could have been because of an internal autoclaving condition resulting from the high temperature and water evaporation due to the improved hydration of the non-hydrated cement grains [28]. This is observed particularly in high-strength concrete because its low permeability resists moisture flow. When the temperature is less than $400{ }^{\circ} \mathrm{C}$, the vapor pressure from the evaporation of the free water in the capillary pores of self-compacting or high-strength concrete is believed to cause decreases in the compressive strength and modulus of elasticity. The pores are pressed during the hot compression test, increasing the vapor pressure and then intensifying the damage to the concrete. Above $400{ }^{\circ} \mathrm{C}$, the cracks in the transition zone dominate the reductions of compression force and modulus of elasticity [2]. Statistical data indicated that the composition was significant (with 97\% confidence interval) on the compressive strength of concrete, and the temperature had a significance level of 94\% (Table II). Thus, temperature and composition were significant. For the composition, the best fit was obtained using a quadratic function; for temperature, it was a linear function. The coefficient of determination $\left(\mathrm{R}^{2}\right)$ of the model fit was 0.88 . The highest compressive strength was observed in composition 2 for the temperature of $450{ }^{\circ} \mathrm{C}$, evidencing the influence of temperature on the compressive strength of concrete. The increased strength could have been due to the formation of C-A-H (hydrated calcium aluminate) gel by the additional hydration of the anhydrous calcium aluminate cement [19].

Tensile strength by diametral compression: similar to the results obtained in the axial compression strength, Fig. $6 \mathrm{~b}$ indicates that for the tensile strength by diametral compression, compositions 1 and 3 suffered a reduction in the strength with the increase of the temperature, whereas for composition 2 there was an increase in the strength at $450{ }^{\circ} \mathrm{C}$. With a temperature increase, microcracks were created, along with the decomposition of $\mathrm{Ca}(\mathrm{OH})_{2}$ and other hydrates, making the concrete tensile strength more sensitive to high temperatures and crack formation than compressive strength, corroborating other results $[29,30]$. The analysis of 

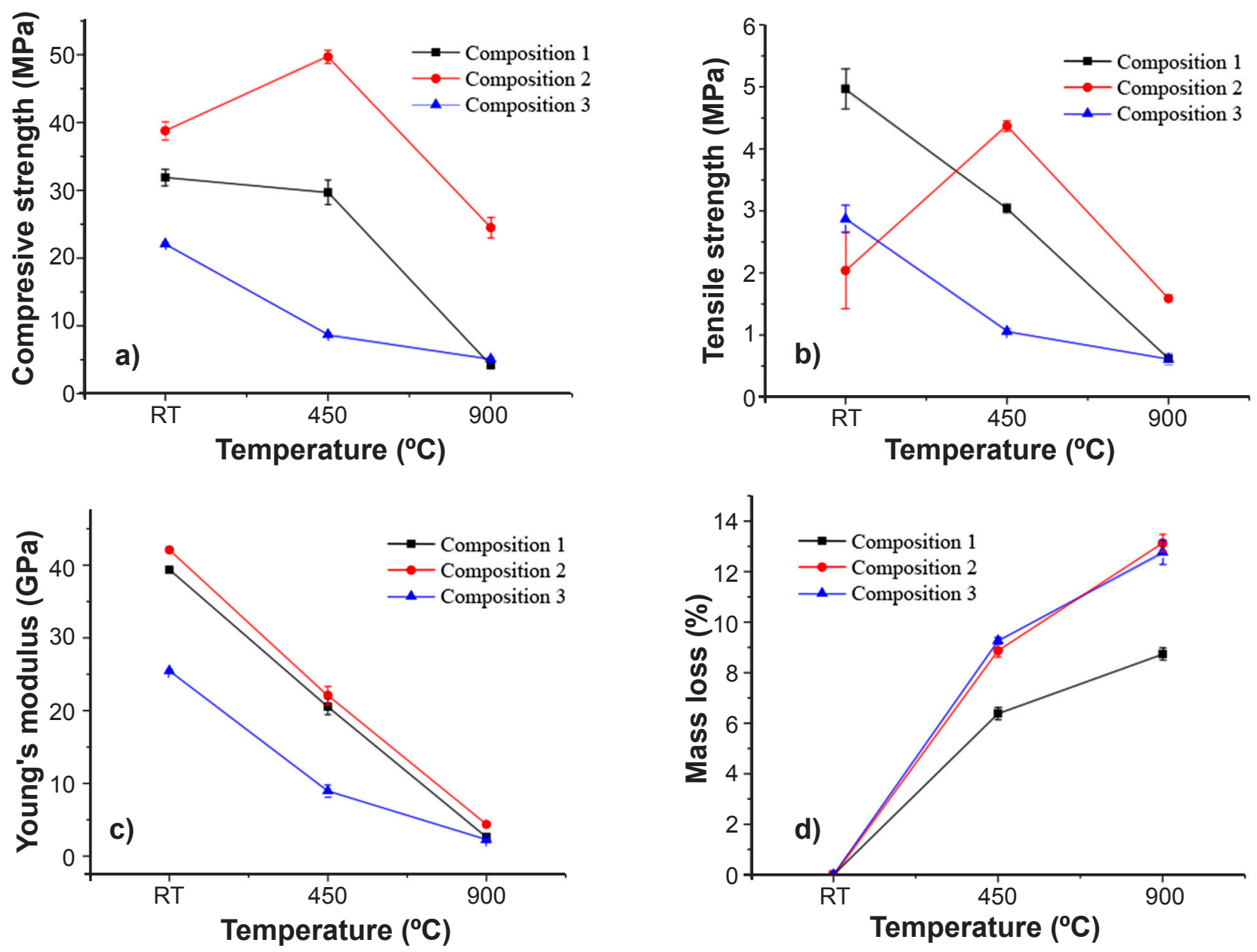

Figure 6: Axial compressive strength (a), tensile strength by diametral compression (b), Young's modulus (c), and mass loss (d) of the samples after heating at the indicated temperature. RT: room temperature.

[Figura 6: Resistência à compressão axial (a), resistência à tração por compressão diametral (b), módulo de Young (c) e perda de massa (d) das amostras após aquecimento na temperatura indicada. RT: temperatura ambiente.]

variance (ANOVA) for tensile strength (Table II) presented a significance level of $80 \%$ for the temperature. According to the Pareto chart, the significance level was $80 \%$ for the temperature on the tensile strength. The $\mathrm{R}^{2}$ was 0.63 , still considered explanatory to the model. With increasing temperature, the tensile strength by diametral compression decreased; however, the means were significantly similar to each other.

Young's modulus: it was observed that the three compositions had a reduction of the modulus of elasticity values with the increase of temperature (Fig. 6c). It has been shown that Young's modulus of concrete decreases with increasing temperature; however, at a virtually linear rate [2]. With a significant reduction of the modulus of elasticity, deformations can occur in the structural elements, making them unsuitable for use [16]. As the temperature increased, the hardened cement matrix first expanded and then contracted owing to water loss, whereas the aggregates continued to expand throughout the heating. Thus, the expansion difference between the materials produced tension stress between the cement matrix and aggregates, causing the formation of microcracks in the transition zone [2], and a detrimental effect on the modulus of elasticity. The ANOVA (Table II) indicated that the composition and temperature were significant for the modulus of elasticity of the concrete (significance level of $93 \%$ and $99 \%$, respectively). The adjustment to model $\left(\mathrm{R}^{2}\right)$ was 0.96 . The Pareto graph indicated that temperature exerted a greater influence than composition on the elastic modulus of concrete. The mean graph indicated the reduction of the modulus of elasticity values with the temperature increase. The values of modulus of elasticity were distinct for the three compositions.

Mass loss: it was observed that the mass loss increased progressively with the temperature increase for the three analyzed compositions (Fig. 6d). The literature indicates that under high temperatures, the degradation process begins with the decomposition of ettringite at $80{ }^{\circ} \mathrm{C}$ [8]. Following the increase in temperature, the cement paste begins the dehydration process, initially with the evaporation of capillary waters, followed by the evaporation of the lamellar waters [8]. Hydration products completely lose their free water and physically absorbed water and begin to lose their chemically bound water at $105{ }^{\circ} \mathrm{C}$ [17]. The increase of the porous structure is mainly responsible for 
the reduction of the mechanical properties [2]. Portlandite $\left[\mathrm{Ca}(\mathrm{OH})_{2}\right]$ dehydration occurs at $500{ }^{\circ} \mathrm{C}$, which justifies the mass loss at this temperature range [18]. At $670{ }^{\circ} \mathrm{C}$, calcite $\left(\mathrm{CaCO}_{3}\right)$ decarbonation occurs, resulting in the release of carbon dioxide $\left(\mathrm{CO}_{2}\right)$ and the formation of calcium oxide $(\mathrm{CaO})$. The mass loss above $700{ }^{\circ} \mathrm{C}$ can be related to the decomposition of the cement paste and aggregates [29]. The ANOVA for mass loss (Table II) indicated that composition and temperature were significant, with $86 \%$ and $99 \%$ confidence intervals, respectively. The $\mathrm{R}^{2}$ fit to model was 0.97 . According to the Pareto graph, the temperature had a greater influence on mass loss. The average graph indicated that the higher the temperature, the higher the mass loss. Furthermore, composition 1 was visibly distinct from compositions 2 and 3. The higher mass losses for compositions 2 and 3 were attributed to the dehydration of the hydrates from the calcium aluminate cement [19].

Optical microscopy: Fig. 7 shows the optical micrographs of each composition before $\left(23^{\circ} \mathrm{C}\right)$ and after heating at 450 and $900{ }^{\circ} \mathrm{C}$. It was possible to verify the transition zone formed between the coarse aggregate and cement paste, at the interface between the large aggregate particles and the hydrated cement paste. It was also possible to observe that the two macroscopic phases of the structure (aggregate and cement paste) were nor homogeneous, neither evenly distributed, as noted in other research [16]. As the temperature increased, the colors of the concrete changed, which could be related to the loss of strength suffered by the material through heat exposure [16].

Scanning electron microscopy (SEM): Fig. 8 shows SEM micrographs of the compositions for the three temperatures studied. Fig. $8 \mathrm{a}\left(23^{\circ} \mathrm{C}\right)$ shows the cement paste interrupted by the presence of the transition zone at the paste/coarse aggregate interface. Figs. $8 \mathrm{~b}$ and $8 \mathrm{c}$ (450 and $900{ }^{\circ} \mathrm{C}$, respectively) indicate a rougher cement paste matrix compared to Fig. 8a. Fig. 8b indicates the presence of cracks near the transition zone. In Fig. 8c, the presence of cracks in both the cement paste and coarse aggregate is shown, in addition to the expansion of the transition zone. The marginally cohesive and discontinuous appearance of the material at $900{ }^{\circ} \mathrm{C}$ was due to the dehydration and transformation of silicates [16]. Up to approximately $300{ }^{\circ} \mathrm{C}$, there is no significant change in the concrete; however, there are significant changes in the aggregate and mortar phases above this temperature [1]. Nevertheless,

Table II - Results of ANOVA for compressive strength, tensile strength, Young's modulus, and mass loss for composition 1, 2 , and $3(0,100 \%$, and $50 \%$ of refractory cement, respectively).

[Tabela II - Resultados de ANOVA para resistência à compressão, resistência à tração, módulo de elasticidade e perda de massa para composição 1, 2 e 3 (0, 100\% e 50\% de cimento refratário, respectivamente).]

\begin{tabular}{|c|c|c|c|c|c|}
\hline Control factor & SS & DF & MS & $\mathrm{F}$ & p-value \\
\hline \multicolumn{6}{|c|}{ Axial compressive strength } \\
\hline (1) Composition L+Q & 1007.36 & 2 & 503.68 & 8.49 & 0.036 \\
\hline (2) Temperature L+Q & 716.84 & 2 & 358.42 & 6.04 & 0.062 \\
\hline Error & 237.24 & 4 & 59.31 & & \\
\hline Total SS & 1961.44 & 8 & & & \\
\hline \multicolumn{6}{|c|}{ Tensile strength by diametral compression } \\
\hline (1) Composition L+Q & 3.23 & 2 & 1.62 & 0.86 & 0.489 \\
\hline (2) Temperature L+Q & 9.31 & 2 & 4.65 & 2.48 & 0.199 \\
\hline Error & 7.51 & 4 & 1.88 & & \\
\hline Total SS & 20.05 & 8 & & & \\
\hline \multicolumn{6}{|c|}{ Young's modulus } \\
\hline (1) Composition L+Q & 191.62 & 2 & 95.81 & 5.29 & 0.075 \\
\hline (2) Temperature L+Q & 1590.33 & 2 & 795.17 & 43.91 & 0.002 \\
\hline Error & 72.44 & 4 & 18.11 & & \\
\hline Total SS & 1854.39 & 8 & & & \\
\hline \multicolumn{6}{|c|}{ Mass loss } \\
\hline (1) Composition L+Q & 10.53 & 2 & 5.27 & 3.41 & 0.1369 \\
\hline (2) Temperature L+Q & 211.51 & 2 & 105.75 & 68.38 & 0.0008 \\
\hline Error & 6.19 & 4 & 1.55 & & \\
\hline Total SS & 228.23 & 8 & & & \\
\hline
\end{tabular}

SS: sum of square; DF: degree of freedom; MS: mean square; F: Fisher's ratio; p-value: probability value. 

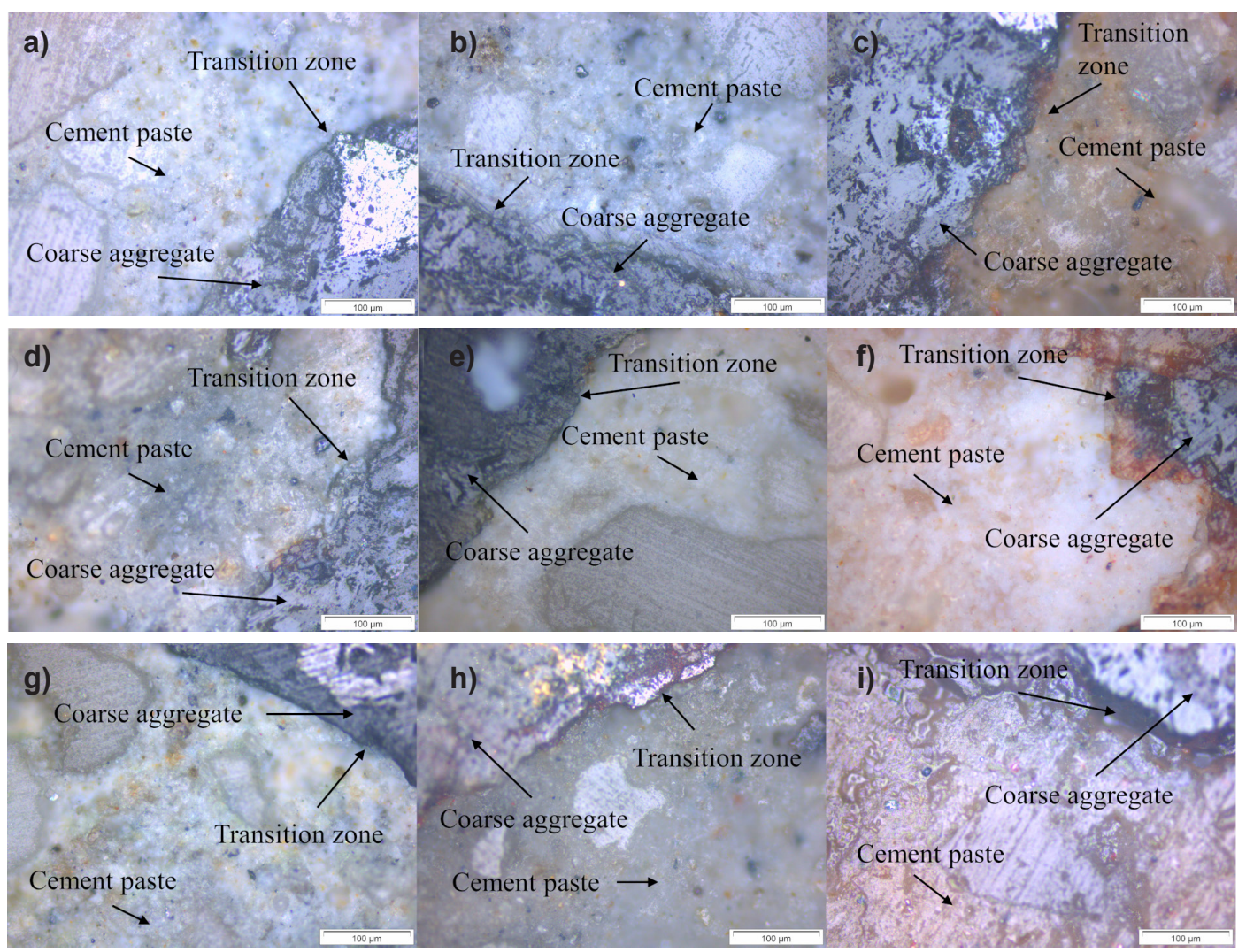

Figure 7: Optical micrographs of composition 1 (a-c), 2 (d-f), and 3 (g-i) exposed to room temperature (a,d,g), $450{ }^{\circ} \mathrm{C}(\mathrm{b}, \mathrm{e}, \mathrm{h})$, and $900{ }^{\circ} \mathrm{C}(\mathrm{c}, \mathrm{f}, \mathrm{i})$. [Figura 7: Micrografias ópticas da composição 1 (a-c), 2 (d-f) e 3 (g-i) exposta a temperatura ambiente $(a, d, g), 450{ }^{\circ} \mathrm{C}(b, e, h)$ e $\left.900{ }^{\circ} \mathrm{C}(c, f, i).\right]$
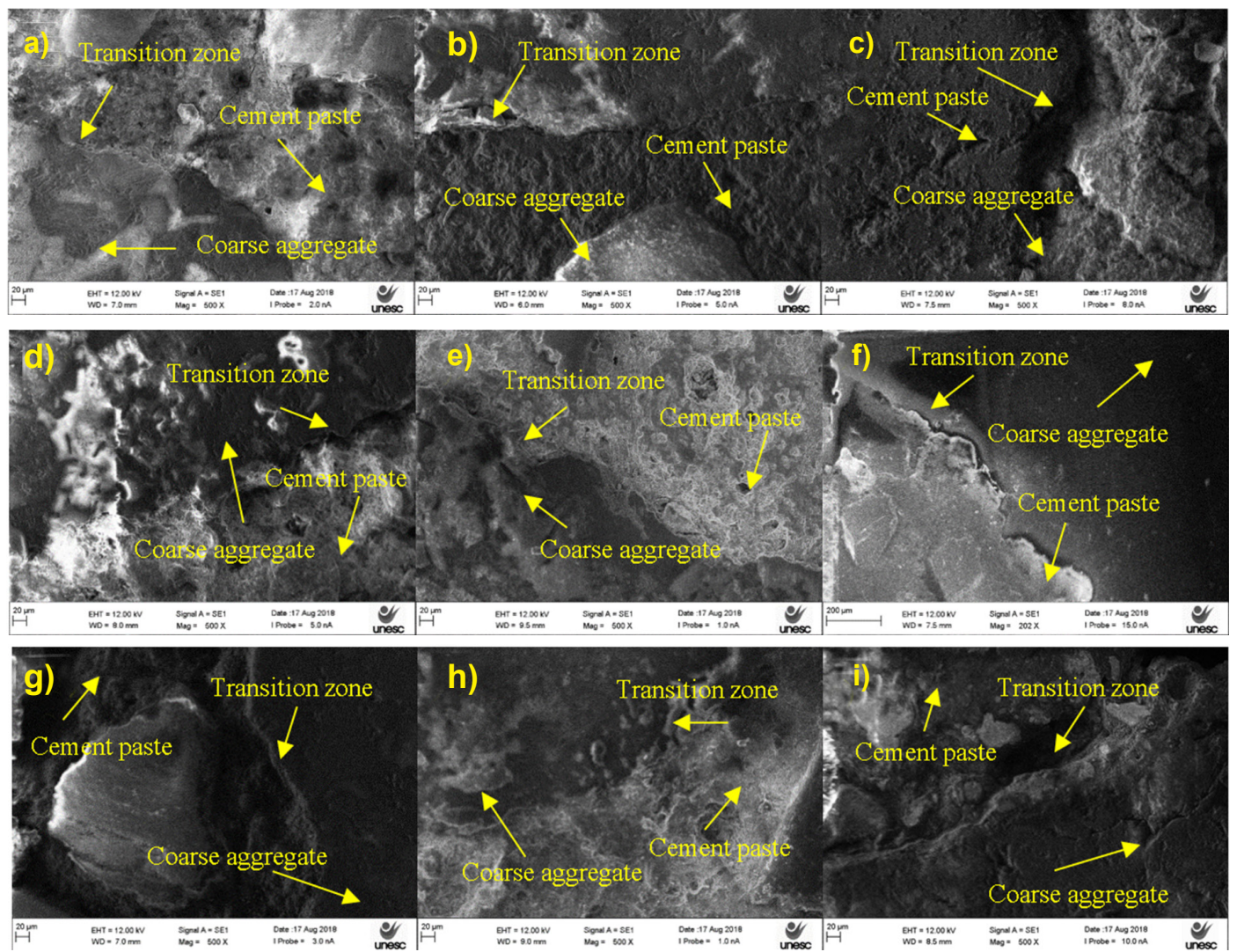

Figure 8: SEM micrographs of composition 1 (a-c), 2 (d-f), and 3 (g-i) exposed at room temperature (a,d,g), $450{ }^{\circ} \mathrm{C}(\mathrm{b}, \mathrm{e}, \mathrm{h})$, and $900{ }^{\circ} \mathrm{C}(\mathrm{c}, \mathrm{f}, \mathrm{i})$. [Figura 8: Micrografias de MEV da composição 1 (a-c), 2 (d-f) e 3 (g-i) exposta a temperatura ambiente $(a, d, g), 450{ }^{\circ} \mathrm{C}(b, e, h)$ e $\left.900{ }^{\circ} \mathrm{C}(c, f, i).\right]$ 
the thermal stresses caused by the different expansions of the aggregates and hardened cement matrix result in the development of high-temperature microcracks [2]. For composition 2, with increasing temperature, the adhesion between the paste and aggregates (transition zone) and cracking of the matrix were observed. In Fig. $8 \mathrm{e}\left(450{ }^{\circ} \mathrm{C}\right)$, a more porous matrix can be verified compared to the sample at room temperature (Fig. 8d). Regarding calcium aluminate cement at $200{ }^{\circ} \mathrm{C}$, densely compacted crystals of $\mathrm{C}_{3} \mathrm{AH}_{6}$ and $\mathrm{AH}_{3}$ cover the pores within the hydrates, producing a dense microstructure; at $450{ }^{\circ} \mathrm{C}$ the same crystals appear dehydrated, presenting a rougher matrix and the presence of voids due to the evaporation of chemically combined water [6]. At $900{ }^{\circ} \mathrm{C}$, the microstructure of composition 2 was denser compared to composition 1, which could be due to the presence of $\mathrm{AH}_{3}$ gel covering the $\mathrm{C}_{3} \mathrm{AH}_{6}$ crystals and the formation of a vitreous phase $[6,30]$.

Figs. 8g to 8i show SEM micrographs for composition 3 for each studied temperature, which indicates the presence of a rougher matrix as the temperature increased. In Fig. 8h, there is an increase in pore volume after exposure to $450{ }^{\circ} \mathrm{C}$ resulting from the evaporation of water in the intermediate layer and pores of the gel, a shrinkage of the hydrated calcium aluminate cement gels, and a transformation and decomposition of the Portland cement silicates [16, 19]. After exposure to $900{ }^{\circ} \mathrm{C}$ (Fig. 8i), cracks in the aggregate and paste was observed. Moreover, a remarkable expansion of the transition zone at the aggregate/matrix interface due to the complete dehydration and decomposition of the hydrates present in the cement paste was visible. When analyzing the micrographs comparing the different compositions $(1,2$, and 3$)$, the differences in the samples at room temperature were not clearly shown (Figs. 8a, 8d, and $8 \mathrm{~g}$ ). However, when the micrographs were compared considering the rise in temperature (Figs. $8 \mathrm{~b}, 8 \mathrm{e}$, and $8 \mathrm{~h}$ at $450{ }^{\circ} \mathrm{C}$, and Figs. $8 \mathrm{c}, 8 \mathrm{f}$, and $8 \mathrm{i}$ at $900{ }^{\circ} \mathrm{C}$ ), differences between the number of cracks and even voids were seen. The differences were noticeable both between the different compositions and with the increase in temperature. Previous studies in which samples were exposed to temperature rise had similar behaviors $[6,30]$.

\section{CONCLUSIONS}

It was concluded from the obtained results in the axial compression test that the composition with refractory cement presented a higher strength when compared to the composition containing Portland CP II-Z32 and mixed composition (50\% Portland CPII-Z32 and 50\% refractory cement) at the three temperature levels. The same was true for Young's modulus, which can be attributed to the formation of a C-A-H (hydrated calcium aluminate) gel. For the tensile strength test using diametral compression, no significant difference was evidenced between the samples. Compositions with $50 \%$ and $100 \%$ refractory cement replacing CPII-Z32 cement demonstrated higher mass loss values compared to the composition with $100 \%$ Portland
CPII-Z32, which could have been due to the dehydration of the hydrates from calcium aluminate cement. A thermal study determined that the composition of Portland CPII-Z32 required less time to attain the maximum temperature at the surface and interior of the concrete. It also indicated a higher maximum internal temperature (difference of 16 $\left.{ }^{\circ} \mathrm{C}\right)$ compared to the composition of refractory cement, demonstrating lower heat conduction in the concrete made with refractory cement, which can be attributed to the dehydration of the calcium aluminate cement. In general, it was concluded that in the event of a fire, the use of refractory cement in the concrete production could result in superior mechanical properties compared to the concrete made with Portland cement in terms of structural stability. This fact highlights the importance of using refractory cements to prevent the effects of fires on concrete structures and could be an option with significant safety gains.

\section{REFERENCES}

[1] L. Biolzi, S. Cattaneo, G. Rosati, Cem. Concr. Compos. 30 (2008) 907.

[2] Q. Ma, R. Guo, Z. Zhao, Z. Lin, K. He, Constr. Build. Mater. 93 (2015) 371.

[3] V.A. Abyzov, Proc. Eng. 150 (2016) 1440.

[4] W.G. Bareiro, F.A. Silva, E.D. Sotelino, O.F.M. Gomes, Constr. Build. Mater. 187 (2018) 1214.

[5] A. Baradaran-Nasiri, M. Nematzadeh, Constr. Build. Mater. 147 (2017) 865.

[6] W. Khaliq, H.A. Khan, Constr. Build. Mater. 94 (2015) 475.

[7] W.G. Bareiro, F.A. Silva, E.D. Sotelino, Constr. Build. Mater. 240 (2020) 117881.

[8] B. Fernandes, A.M. Gil, F.L. Bolina, B.F. Tutikian, Rev. Ibracon Estrut. Mater. 10 (2017) 838.

[9] B.L. Karihaloo, Fracture mechanics and structural concrete, Longman Publ., Essex (1995) 330.

[10] NBR 5738, "Concreto: procedimento para moldagem e cura de corpos de prova", Ass. Bras. Norm. Técn., Rio Janeiro (2015).

[11] NBR 5739, "Concreto: ensaio de compressão de corpos de prova cilíndricos", Ass. Bras. Norm. Técn., Rio Janeiro (2018).

[12] RILEM TC 129 MHT, "Test methods for mechanical properties of concrete at high temperatures, part 9: shrinkage for service and accident conditions", Mater. Struct. 33 (2000) 224.

[13] NBR 7222, "Concreto e argamassa: determinação da resistência à tração por compressão diametral de corpos de prova cilíndricos”, Ass. Bras. Norm. Técn., Rio Janeiro (2011).

[14] NBR 8522, "Concreto: determinação dos módulos estáticos de elasticidade e de deformação à compressão", Ass. Bras. Norm. Técn., Rio Janeiro (2017).

[15] N. Yuzer, F. Akoz, L.D. Ozturk, Cem. Concr. Res. 34 (2004) 1803.

[16] R.C. de Lima, "Investigação do comportamento de 
concretos em temperaturas elevadas", Dr. Thesis, Un. Fed. Rio Grande Sul, Porto Alegre (2005).

[17] R.F. Feldman, V.S. Ramachandran, Cem. Concr. Res. 1 (1971) 607.

[18] I. Hager, Bull. Pol. Acad. Sci. 61 (2013) 145.

[19] N.K. Lee, K.T. Koh, S.H. Park, G.S. Ryu, Cem. Concr. Res. 102 (2017) 109.

[20] J. Soro, A. Smith, C. Gault, J. Eur. Ceram. Soc. 26 (2006) 3799.

[21] Q. Zhang, D. Yan, Adv. Cem. Res. 28 (2016) 576.

[22] J. Piasta, Z. Sawicz, L. Rudzinski, Mater. Constr. 17 (1984) 291.

[23] G.-F. Peng, Z.-S. Huang, Constr. Build. Mater. 22 (2008) 593.
[24] R.K. Ibrahim, R. Hamid, M.R. Taha, Constr. Build. Mater. 36 (2012) 779.

[25] R. Kowalski, Archit. Civ. Eng. Environ. 3 (2010) 61.

[26] B. Georgali, P.E. Tsakiridis, Cem. Concr. Compos. 27 (2005) 255.

[27] M. Saad, S.A. Abo-El-Enein, G.B. Hanna, M.F. Kotkata, Cem. Concr. Res. 26 (1996) 669.

[28] H.F.W. Taylor, Cement chemistry, Thomas Telford (1997) 449.

[29] A.L. de Castro, P.R.T. Tiba, V.C. Pandolfelli, Cerâmica 57, 341 (2011) 22.

[30] Y.R. Krivoborodov, S.V. Samchenko, T.V. Kuznetsova, Refract. Ind. Ceram. 59 (2018) 151.

(Rec. 19/12/2019, Rev. 19/03/2020, 07/04/2020, Ac. 10/04/2020) 